\title{
LEGAL AND ECONOMIC IMPLICATIONS OF THE GERMAN CRAFT CODE AMENDMENT 2004
}

\author{
W. Benzel
}

Received: November 30, 2011

\begin{abstract}
BENZEL, W.: Legal and economic implications of the German Craft Code Amendment 2004. Acta univ. agric. et silvic. Mendel. Brun., 2012, LX, No. 2, pp. 25-36

As the main reason for initiating an amendment of the Trade and Crafts Code in 2004 was the decrease in the number of companies in general and the number of skilled crafts enterprises in particular and was also due to the fact that the number of employees in the skilled crafts sector had constantly fallen and many companies were not able to find a successor, it was the declared aim of the amendment to counter this structural crisis as well as reducing illegal employment and removing native discrimination. This would then ensure a higher level of employment especially through new company formations and takeovers of existing companies.

In addition to providing an important contribution towards the assessment of the basic success of the 2004 Trade and Crafts Code amendment, the results can therefore be used at an international level for discussions on skilled crafts legislation outside Germany. As German skilled crafts legislation developed in a completely different manner from skilled crafts legislation in most other European countries, this aspect is particularly significant and it is conceivable that the results will be useful beyond the borders of the Federal Republic of Germany.

The research findings will also be important in determining the limits of deregulation and when it can be considered counterproductive from an economic point of view.
\end{abstract}

skilled crafts, masters degree, market rstrictions, regulation, deregulation, competition

Market access restrictions and self-regulating features are in Germany a wide-spread instrument in order to regulate the market and the competition. This concerns, besides the so-called "liberal professions or freelance professions" also some other commercial professions, which are subject to approval, especially the handicraft pursuits. ${ }^{1}$
A central announced argument for the basically necessity of market access barriers by liberal professions and handicraft pursuits, is especially the existence of asymmetrical information between supply- and demand, the establishment of a highgraded quality standard, ruinous competition between the enterprises and transaction-

1 As an example of the professions, unlimited assistance in tax matters from a business point of view can only be offered by those who are authorised to do so ( $\$ 2$ StBG - tax advisory law). Those authorised to give unlimited assistance in tax matters are mainly tax consultants, tax agents, lawyers, established European lawyers, auditors and sworn auditors as well as partnerships and incorporated companies, that are subject to the further provisions of the tax advisory law (cf. in addition to $\$ 3$ StBG - especially $\$$ 35-55 StBG).

Businesses which are subject to authorization such as private clinics, the manufacture of orthopaedic custom-made footwear, brokers and builders are standardized in $\$ \$ 29-40$ GewO ( Industrial Code) (companies which require special authorization). Exceptions to the applicability of the Industrial Code to businesses can be found in $\& 6$ GewO - based on the existence of further special laws. Cf. on this topic Stober, Gewerbeerlaubnisrecht, in: NWB no. 32 of 03.08.1998, F. 30 S. 1159; also $\& 6$ GewO defines the non-applicability of the GewO to part of the professions, namely those professions that serve the administration of justice.

Reference is made here and as follows to the Industrial Code of 21. June 1869 (RGBl. p. 245) in the new version of 22. February 1999 (BGBl. I - German Civil Code - p. 202). 
cost rises, followed by no optimal resulting resource-allocations. ${ }^{2}$ In the industry area $^{3}$ the standardisation of permission obligations serves in form of approvals, authorisations, concessions or licenses ${ }^{4}$ as trade-liberal-correcting measures to prevent from danger proceeding and emerge from the community or business cycles of the respective trade activities ${ }^{5}$ to be protected. The most important argument in the handicraft trade area regarding the establishment of the market barriers is the existence of the major certification of aptitude. ${ }^{6}$ The major certification of aptitude shall guarantee customers a high-graded handicraft work quality, what furthermore leads to an equastion of the information asymmetries ${ }^{7}$. Further arguments of the proponents are the high performance-level and the readiness of the craftsmen, guaranteed through the essential master craftmen's degree obligations. Moreover, the apprenticeships to be served in the handicraft business area forms the basic conditions for a "solidity culture", which led to a mental image of the employees. In the consequence, the development of a specific specialised-craftsmenhuman-capital became possible. On the basis of this personnel infra structure it became possible to guarantee for products and services of high-graded quality, what strengthend the competitiveness of the German economy ${ }^{8}$.

Furthermore, comment the proponents regarding the coherence between the master craftmen's degree obligation as a settlement pre-conditions for crafts and also the thereout resulting authorisation to execute apprentice training and qualification performances on their work floors. Only through the retention of this coherence is it possible, to ensure the apprenticeship-cooperativeness of the handicraft pursuits. The training cooperativeness itself is necessary to ensure that the professional training also exceeds the demands of the handicraft pursuits 9 . A further argument is, that the major certification of aptitude prevents the access of dabblers into the handicraft market. This is necessary, in order to prevent that master handicraft companies, which offer products of high-graded quality, are superseded through dubious price structures of the dabblers. Thereby a ruinious competition would appear to the disadvantage of the customer, of course, because the relevance of the work-quality would turn out of the customers' field of vision ${ }^{10}$. Thus the proponents of the major certification of aptitude opine, that they cannot abandon the major certification of aptitude because of its function as a market-entering-barrier. ${ }^{11}$

Reviewers do not unanimously agree to this opinion and they point out, that the establishment of the major certification of aptitude serves more for the foreclosure of the market and therewith for the own benefice security ${ }^{12}$.

While in not legal regulated markets the mechanism regarding supply and demand

2 Cf. Kucera/Stratenwerth, Deregulierung des Handwerks: Gesamtwirtschaftliche Risiken und Gefahren. Survey carried out by order of the Deregulation Commission for the Federal Minister of Economic Affairs, 1989, p. 49 et seq.

3 Here we must keep in mind that skilled crafts and businesses are not mutually exclusive and there are considerable overlaps or rather superordinate/subordinate relationships (cf. below). The distinction between barriers to market entry discussed here is based on various legal foundations, namely the Trade and Crafts Code and the Industrial Code, whereby trade law was excluded from the Industrial Code; cf. on this Stober, Besonderes Wirtschaftsverwaltungsrecht, 2001 p. 2.

$4 \S 15$ para. 2 GewO.

5 Cf. Stober, Gewerbeerlaubnisrecht, in: NWB No. 32 of 03.08.1998, F. 30 S. 1159; for the prevention of risks and the further limitation on freedom of trade connected with it cf. also Stober, Wirtschafts- und Gewerbeüberwachung, in: NWB No. 5 of 01.02.1999, F. 30 p. 1205 et seq. as well as Stober, Gewerbeuntersagung, in: NWB No. 26 of 28.06.1999, F. 30 p. 1235 et seq.

6 Whilst the "Minor Certificate of Aptitude" connected the right to train apprentices with the successful completion of the Master's examination, the "Major Certificate of Aptitude" connected the right to carry out a skilled craft independently with the acquisition of the Master title. On this: Deregulierungskommission: Marktöffnung und Wettbewerb, 1991, p. 117.

7 ZDH (German Confederation of Skilled Crafts), Stellungnahme zum Großen Befähigungsnachweis und zur Bedeutung der Handwerksordnung als Voraussetzung für den hohen Leistungsstand des deutschen Handwerks und die Sicherung hochwertiger Aus- und Weiterbildung im Interesse der Gesamtwirtschaft, 1988, p. 32.

8 Klemmer / Schrumpf, Der Große Befähigungsnachweis im deutschen Handwerk, 1999, p. 20 et seq.

9 Cf. on this point Albach, Zur Wiederentdeckung des Unternehmens in der wirtschaftspolitischen Diskussion. Zeitschrift für die gesamte Staatswissenschaft, Heft 135, 1989, p. 535 et seq., Kucera/Stratenwerth, Deregulierung des Handwerks: Gesamtwirtschaftliche Risiken und Gefahren. Survey completed by order of Deregulation Commission for Federal Minister of Economic Affairs, 1989, p. 1 et seq.; ZDH (Confederation of Skilled Crafts), Stellungnahme zum Großen Befähigungsnachweis und zur Bedeutung der Handwerksordnung als Voraussetzung für den hohen Leistungsstand des deutschen Handwerks und die Sicherung hochwertiger Aus- und Weiterbildung im Interesse der Gesamtwirtschaft, 1988.

10 Klemmer / Schrumpf, Der Große Befähigungsnachweis im deutschen Handwerk, 1999, p. 21.

11 Wallenberg, Die Bedeutung des Meisterbriefs in Zeiten von Qualitätsmanagement und Europäischen Normen. Europäische Zeitschrift für Wirtschaftsrecht, Heft 6, 1995, p. 396 et seq.

12 On the opinion that the Major Certificate of Aptitude is neither a guarantee of professional execution of skilled crafts services nor of entrepreneurial responsible action cf. Pütz/Meyerhöfer, Hemmnisse und Hilfen für Unternehmensgründungen, 1982, p. 302 et seq.; on the argument concerning market foreclosure and protection of privileges cf. Neubacher, Kartell im Cyberspace, in: Der Spiegel, issue 10/2000 of 04.03.2000. 
produces an regulating effect and the price overtakes the allocation functions ${ }^{13}$, functions such an automatism by the consideration of the current legal restrictions only in a reduced form. Therefore are regulating markets extremely forced to adapt to the permanently changing conditions of the environment and market situation through the alteration of the legal basic conditions, in order to survive against existence-violations in this competition-oriented national economy. Especially the retention of such originally meaningful restrictions can lead, through the noneoberservance of such adaptations, to a contrary effect. Legal restrictions must on the one hand side relate to an undetermined quantity of individuals, to be able to guarantee the same treatment valid for everybody, in order to achieve the legal restrictions' objectives. On the other hand they shall forbid undisireable behaviours but shall not prescribe specific behaviour patterns. Only then can market forces develop and unfold free. If specific behaviour patterns were prescribed, would this work against the basic conditions of a functioning market economy system, namely the effective problem solution through the involvement of several individuals on a solution-searching-process ${ }^{14}$. Is, however, the normative environment too tight and the adaptation ability, in form of reform abilities not established enough, leads the market regulation in the consequence to an over- or faulty regulation with counter-productive consequences. It is only in a reduced form possible for the individuals, involved in such a case, to act in the sense of flexible and efficient problem solution. As especially the supplying part of a regulated market cannot itself react to their participants due to the legal restrictions, or if so only in reduced form can react to the alteration requirements - but only indirect, for example, over lobbies such as federations and chambers, in order to change the actual legal basic conditions. Therefore are regulated markets restricted in their adaptation flexibility ${ }^{15}$. Mr. Albach speaks from a tendential „structurepreserving" effect, because the dynamical competition forces are paralysed through the market-entering-barriers ${ }^{16}$. But, however, due to the necessary adaptation demands, which follow after each structural change, need laws in serveral areas permanently modifications due to the continuously changing situations. Stand national standards in the international competition of systems and is the danger of being subject of existent-threatments existing, leads that to the fact, that the reform pressure increases permanently ${ }^{17}$.

Actual developments such as the free trade transport of goods, services, funds and workmenships within the EU, but also the continual development of the knowledge based society as well as alterations on the finance market, form since quite some time, the basis of keen discussions around the deregulation of various market-access-barriers matters $^{18}$ and therewith also around the major certification of aptitude ${ }^{19}$. The discussions regarding the major certification of aptitude acts in its core exactly before the mentioned background of the international, European-wide, system competition and a not existing, or only in reduced form existing, adaptation-flexibility of the German systems. Both fields exhibit strong interdependencies and should not be seen as separate parts but in their full coherence. The main requirements, in the scope of executed discussions, reach hereby from the retention ${ }^{20}$ of the major certification of aptitude over the liberalization of market-entering-restrictions ${ }^{21}$ up to the complete removal of the master'sdegree compulsion ${ }^{22}$. There are even opinions represented, which require ${ }^{23}$ an extention of the established market-entering-restrictions and also an extention of the enclosure $A$ of the handicraft ordinance (trade registry, which includes the various

13 Cf. Stobbe, Volkswirtschaftslehre I, Volkswirtschaftliches Rechnungswesen, 1984, p. 17 et seq.

14 Cf. Hayek, Die Verfassung der Freiheit, 1971, p. 193.

15 Stober (Besonderes Wirtschaftsverwaltungsrecht, 2001, p. 3 et seq.) shows with the example of many attempts to reform the Industrial Code, how tough such an adjustment process can be. With the example of trade law, this process is still continuing after a discussion which has been going on for decades, and despite a few changes, the aim of implementing a legislative reform has still not been achieved. On the other hand, he also poses the question as to whether there is a need for adjustment at all in such a case since there is no pressure for an amendment.

16 Albach, Deregulierung des Handwerks, 1992, p. 3.

17 Cf. on this point Giersch, Eurosclerosis. 1985; As a more recent example of adjusting to changes in the professional environment and in this connection especially to an increasing internationalisation and due to the advancing development of a global capital market cf. the changes to Auditors' Code, on this point: Kahling, Wirtschaftsprüfung im Umbruch, in: StuB, issue 13/2000, p. 670 et seq.

$18 \mathrm{Cf}$. as an example of this the discussion on the liberalisation of the authority to offer unrestricted assistance in tax matters, which find their expression in the 7th amending act to the tax advisory law. An overview: Krumbholz, Entwurf des 7. Änderungsgesetzes zum StBerG und zur Änderung anderer Gesetze, in: StuB, issue 20/1999, p. 1096 et seq.

19 Cf. KfW, Das Handwerk im Wandel, p. 28.

20 Klemmer / Schrumpf, Der Große Befähigungsnachweis im deutschen Handwerk, 1999.

21 Reformkommission Soziale Marktwirtschaft, Die Renaissance der Selbständigkeit, 1999.

22 Opinion of BUH (professional association of self-employed skilled crafts workers) of 18.11.1998 on XII. Main report of Monopoly Commission; Herz, Wir sind gegen den Meisterzwang, in: Die Zeit, issue 04/2003.

$23 \& 1$ para. $2 \mathrm{HwO}$ (Trade and Crafts Code). 
handicraft business) ${ }^{24}$ against various deregulation requirements. Other parties articulate the idea, in the context of further advancements of the German master's degree training, to introduce Europeanwide a „Euromaster" and additionally to upvalue the master's degree title in the scope of a binary training system compared to an universal training ${ }^{25}$.

Therefore it can not be spoken about agreements within the spectrum of possible alternatives regarding further developments of the master'sdegree-obligations in Germany. How widly the discussions are spread and how intensive they are and which societies are involved in these discussions, can simply be found out through the input of the word "master obligations" into an internet search-engine. The search results are, however, only in reduced form useful to receive a general opinion tendency, because it may come to interest-conditioned distortions. This depends firstly on the fact, that it mostly are elaborated opinions from persons, institutions or parties, which are confronted with the topic of master's-degree obligations. These statements are mostly their own views resp. opinions and do not refer to objective considerations or scientific estimated arguments. It is clear, however, that there are various expressed opinions, which express the disagreements regarding the current valid regulations and the requirement to execute system alterations, with not such much regulations ${ }^{26}$.

\section{Objectives and structure}

This paper presents the summarized evaluation, wether the objectives referring to the german craft code amendment in 2004 are achieved or not.

In the scientifical discussion speak reviewers of the major certification of aptitude regarding the market-entering-barriers, about „political failures“27 and also that "the German regulations for the handicraft business....stand in a opposite position to the diametrical requirements of the global economy"28. Others' say, that "....the handicraft history...a changing story ${ }^{* 29}$ and that these changes „...never the defence, but always the adaptation was the best way of counteracting ${ }^{430}$ in the handicraft business area. In the scope of the held discussions around the major certification of aptitude is visible that the adaptation pressure is very powerful regarding the regulations valid in Germany and that all indications or signs are given for a "change”. Subject of this inside-interest could be, to find out, which influences cause this "change" and whom or what affects the influences of the considerably developing tendencies. To this also belongs the answer of the question how the development in the future will turn out.

Scientifically are thereby different approaches conceivable to deal with the subject "the problems with the change of the master's-degree compulsion". Basically there are philosophical, historical, economic and legal basical approaches. Philosophical approaches deal with the question if self-contained "moraly stages" in the sense of "specific ressort morality ${ }^{\text {"31 }}$ exist and to what extent this step's into contradiction or in competition to (also changeable) the general morality ${ }^{32}$. Historical approaches deal with the context of developments and investigate about actual developments and their causes, in order to make conclusions and to derive among other things the present and future developments ${ }^{33}$.

Economic investigations deal with the core of the question whether market-access-barriers are economically useful and in what respect restriction-

24 Cf. on this point Fuchs/Demmer, Meeting of Federation-State-Committee "Gewerberecht" (trade law), in: GewArch. (trade archive) 1998, p. 372 et seq.

25 Cf. on this point, from the non-academic discussion: Geisler, Euro-Master statt Meister, in: Hamburger Abendblatt, issue dated 06.01.2003.

26 As proof of the non-academic discussion cf. from the vast flood of opinions Rademaker, Grüne wollen Handwerk reformieren, in: FTD, issue dated 27.12.2002; Brors, Handwerk hat doppelten Boden, in: Handelsblatt, issue dated 07.11.2002; Berschens, Union im Bundesrat kontra Trockenbauer, in: Berliner Zeitung, issue dated 06.04.2000; Berschens, „Prägnanter formulieren“, General Secretary Schleyer of German Skilled Crafts Organisation - ZDH on requirement for a Master's qualification, in: Berliner Zeitung, issue dated 16.03.2000; without author, Grüne wollen Reform, in: TAZ, issue no. 6940 dated 28. 12. 2002, p. 2; without author, Streit um den Meisterbrief, in: Rhein-Zeitung, issue dated 14.03. 2003, p. 7; without author, Appell gegen „Meisterzwang in IT-Betrieben, in: Computerwoche, issue no. 48 dated 28. 11. 1997, p. 65; Wacker, Handwerksmeister, mehr als ein Titel, in: Hamburger Abendblatt, issue dated 06. 01. 2003; Meyer, Berufsbild mit Schrammen, in: c`t 9/98; DGB, Stellungnahme zum Abschnitt 5. des 12. main report of Monopoly Commission 1996/1997; an overview of the range of opinions at www.baunetz.de or the many opinions of the BUH at www.buhev.de; further opinions at www.pds-im-bundestag.de; www.gruene-fraktion.de; www.cdu-wiesbaden.de; each with status of May 2003.

27 Blum, Marktzugang und Exportfähigkeit deutscher Dienstleistungsunternehmen, 1998, p. 148.

28 Fredebeul-Krein / Schürfeld, Marktzutrittsregulierungen im Handwerk und bei technischen Dienstleistungen, 1998, p. 148.

29 Battermann, Handwerker handeln im Markt: Grundlagen eines handwerksspezifischen Marketing, 1997, p. 40.

30 Reichling, Wirtschaftliche Entwicklung und Perspektiven des Handwerks, 1992, p. 19.

31 Gehlen, Die Seele im technischen Zeitalter, 1957, p. 107.

32 Schmidt, Standesrecht und Standesmoral, 1992, p. 19.

33 Cf. Barnowski-Fecht, Das Handwerk der Stadt Oldenburg zwischen Zunftbindung und Gewerbefreiheit (1731-1861), 1998, p. 9. 
adaptations of altered environmental conditions are necessary for the advancement of the economical basic conditions. Is through this the competition prevented or cultivated? Up to what extent serve regulations for the avoidance or reduction of market failures? Are requirements to introduce minimum standards for the educational qualification seen as more high-graded as an eventually quality loss of the offered services? Do market-access-barriers anticipate the development of new jobs or do they cultivate the labour market? These are possible questions of economical investigation approaches ${ }^{34}$. Also legal investigation approaches are complex. One the one hand side they deal with the question in which relation market regulations as a partial order system stands in relation to the general legal order system $^{35}$. In the presented case is thereby the handicraft ordinance subject of the interest as a separate part of the trade order system in relation to higher ranked rights, thus first the Basic law, and also in relation to the higher ranked European rights. A partial aspect for this is the question, in what extent a legal order of specific partial order, which applies for everyone, can be permitted ${ }^{36}$. On the other side the legal insight-interest can raise the question, how far the normative boundaries will be sufficient enough in order to achieve the purpose of the legal rights or the investigation of eventually clash of interests between the purpose of a law and the purpose-/target system of a individuum, which underlies normative restrictions.

All these questions form only a part out of various possible investigational interests and this is by far not all. If a total image of possible market regulation developments of the German handicraft business area shall be developed, it seems to be important, that strict separated views between individual scientifical disziplines lead to a wrong, or only partial right, image what relates to the established interdepandences between the individual disziplines. Hereby has to be pointed out, that such a complex investigation is not manageable, in the scope of this dissertation. Draw attention should be served to the fact, that other possible solutions suggested from smaller groups of interest, which are useful in all intents and purposes, are superseded through the more powerful influences of larger lobbies. For instance could due to economical reasons the conclusion to retain the certification of aptitude compulsion be justifiable or to institutionalise it European-wide, while the EU-law-system supersedes this and "forms facts", which leaves the economical explanation regarding the retention or extention, for example, due to the promotion of integartional possiblities within the EU, without notice.

Under consideration of the current European development tendencies and the above mentioned international system competition within the $\mathrm{EU}$, turns the question of the various possible investigational interests in the middle of the center: Firstly, which effect the developing integration process within the EU will have on the emerging development of the master's-degree-compulsion in Germany and secondly, if the German system will affect EU-wide regulations? Additionally should also the question be investigated, if the development is such dominating, on the basis of the competitive law-systems, in order to supersede (if possible partly) others? For instance, the economical motivated developments or if an "integrated solution" is possible? Is it possible to filtre the best interest approaches out of the different law-systems as well as out of the above described individual disciplines (especially the economy) and combine them? The investigational point of interest is not to be understood, however, that one is only possible together with the other, or the other way round. It is rather more meant in that way, that a normative scope serves to enable specific desired economical developments.

A fundamental cognitive interest of the work is therefore to examine initially how the requirement for a Master's qualification relates to European law, which legal system has or had a formative influence on the other and how the German Trade and Crafts Code can develop in the context of internationalisation.

As the main reason for initiating an amendment of the Trade and Crafts Code in 2004 was the decrease in the number of companies in general and the number of skilled crafts enterprises in particular and was also due to the fact that the number of employees in the skilled crafts sector had constantly fallen and many companies were not able to find a successor, it was the declared aim of the amendment to counter this structural crisis as well as reducing illegal employment and removing

34 Against the background of the current economic situation in Germany, the issue of unemployment is of particular importance in the current economic discussion about regulations in the German skilled crafts sector. Cf. on this point Monopoly Commission, Reform der Handwerksordnung, Sondergutachten der Monopolkommission according to $\S$ 44 para. 1 clause 4 GWB, 2002, p. 9 as well as Fredebeul-Krein/Schürfeld, Marktzutrittsregulierungen im Handwerk und bei technischen Dienstleistungen, 1998, p. 1.

35 Schmidt, Standesrecht und Standesmoral, 1992, p. 19.

36 Cf. Westermann, Das Verhältnis von Standesregeln und guten Sitten im Wettbewerbsrecht, 1974, p. 545, 555.

37 Cf. on this point in addition Brenke, Reform der Handwerksordnung - Erfolgreich, aber viel zu halbherzig, in: DIW Berling (Ed.): quarterlies on economic research 77, 2008, p. 51 et seq. as well as Leßmann, Die Novelle der Handwerksordnung, Ich-Ags und die Folgen für das Bauhandwerk, in: ifo Institut (Ed.): ifo Dresden reports, issue 6/2005, p. 28. 
native discrimination. This would then ensure a higher level of employment especially through new company formations and takeovers of existing companies. ${ }^{37}$

On the basis of the insight gained from the first part of the work, an analysis will be undertaken to answer the central question of the work, namely whether the economic and social aims of the amendment to the 2004 Trade and Crafts Code have been successfully achieved. Depending on this result, conclusions can then be drawn both for the economy and for the management of skilled crafts enterprises.

At the same time I will analyse where any positive effects are to be seen, especially in the training of human capital, and deduce from this the quality of any positive effects.

In addition to providing an important contribution towards the assessment of the basic success of the 2004 Trade and Crafts Code amendment, the results of this work can therefore be used at an international level for discussions on skilled crafts legislation outside Germany. As German skilled crafts legislation developed in a completely different manner from skilled crafts legislation in most other European countries, this aspect is particularly significant and it is conceivable that the results will be useful beyond the borders of the Federal Republic of Germany.

The research findings will also be important in determining the limits of deregulation and when it can be considered counterproductive from an economic point of view. Accordingly, a basic statement will then be made concerning the success - or failure - of the amendment against the background of this question.

Eventually the results of the work should provide guidelines for the management of skilled crafts enterprises. The research will focus precisely on the question of how companies can assert themselves in a market which is becoming increasingly deregulated.

\section{METHODS}

Extensive literature research was necessary to deal with this topic. This literature includes relevant dissertations mainly from research work carried out at academic institutes and essays which have been published in the relevant literature.

Furthermore, much of the literature research involved an intensive study of legislation, particularly concerning the decisions of the Federal Constitutional Court and the European Court of Justice.

The investigation into the effects of the Trade and Crafts Code amendment itself will be based on extensive evaluation of statistical material. The methods used for evaluation are described in detail in the following chapter. This is regarded as advisable since it makes it easier to understand how the method and practical analysis fit into the overall context.

\section{RESULTS, CONCLUSIONS AND OUTLOOK}

\section{Need to adapt Trade and Crafts Code}

The development of the German skilled crafts sector and the legislation relating to skilled crafts is characterised by the fact that the guilds played a dominant role from the 12th century at the latest onwards. The guild system typically controlled the organisation of German skilled crafts for several centuries. The constitutions of the guilds with their inherent rights and duties formed the basis for the trade legislation which evolved over time.

One central theme in the history of German skilled crafts development has been the demand for the introduction of a compulsory major certificate of aptitude as well as compulsory membership of a corporation. Another key theme has been the call for comprehensive deregulation and ease of market access. At the same time, it became clear particularly at the end of the 19th century that freedom of trade and the associated easing of entry restrictions for the skilled crafts could not produce a revival in the skilled crafts. Whether the poor situation actually had something to do with the liberation of trade or whether its cause-effect relationship was to be regarded as a completely isolated case in the context of the circumstances of the time, is something we cannot go into here. Suffice to say that no improvements were observed. As a counterargument, the skilled crafts had experienced another downturn about one hundred years previously, despite very strict regulations.

Up until recent times, supporters and critics of regulations used the same arguments more or less continuously to impose their views.

As far as the introduction of the major certificate of aptitude is concerned, the supporters eventually won through at that time. However, it was an irony of history which helped them achieve their supposed success.

Consequently, the arguments for and against are to be weighed up most carefully when assessing the demands for deregulation. After all, we cannot ignore the success of the German skilled crafts sector after 1945 during which time the requirement to hold a Master's qualification has been preserved or rather reintroduced. Indeed close inspection would be required to determine what the consequences would be of a renewed and in many areas almost complete termination of this standard which has been successful for such a long time. On the other hand, there is the view that the regulations which have applied until now may have been appropriate for the past but are no longer suitable for future requirements.

The fact that skilled crafts had been in decline for years combined with the lack of any new 
amendment to the Trade and Crafts Code since 1953 meant that many skilled crafts services were not offered in a way which many different interest groups felt appropriate based on social and economic requirements. There were also demarcation problems between the skilled crafts and other branches of industry.

At the same time, both diverse research institutes and the monopoly commission doubted the economic sense of the very high entry restrictions as a result of the requirement for a Master's qualification. Similarly, reservations relating to both non-craftsmen and the individual trades were also subject to increasingly critical observation. According to experts, negative effects of regulation became apparent in the form of less competition, less players in the market, less start-ups, high prices which were regarded as too high especially in the lower priced market segment and a low level of price elasticity resulting in less employment. The consequences were a slow rate of structural change combined with low willingness to invest. Deficient quality and service were also evident.

These assumptions have been completely confirmed by the economic development in the skilled crafts sector. It has lagged behind the development of the economy as a whole since 1996. This has been evident in decreasing numbers of companies as well as decreasing numbers of employees. At the same time, the number of successfully completed Master examinations has declined. An increase in illegal employment has became evident especially amongst small orders.

Constitutional concerns were expressed regarding the subjective conditions for admission to a profession and this was considered a serious intervention in the basic right of freedom of occupational choice. Such a restriction is only permitted for the protection of an important community asset, which many critics have regarded as not applicable to the restrictions in the skilled crafts. Particularly the judgement of the German Federal Constitutional Court of 1961, which has lost none of its importance over the decades, referred to the "preservation of the standard of performance and efficiency of the skilled crafts" and to "ensuring successful training of young workers for the good of the entire industrial economy". In both cases, however, many people feel there are no community assets requiring protection which would justify a restriction in occupational choice. Rather it is the interests of the community arising from special economic, social and sociopolitical views which are to be regarded as worthy of protection. As the industrial economy outside the skilled crafts sector - in which there is typically no obligation for a Master's examination or similar examinations has developed more dynamically than the skilled crafts sector, we must question how far the reasons recognized by the Federal Constitutional Court of 1961 still apply to the skilled crafts certificate of aptitude. We must take into account here that innovations have simplified numerous crafts activities and the demarcation to industry has consequently become more difficult to define than used to be the case in former times. As a result, either the constitutional justification for the existing restriction of freedom of occupational choice required better validation or the entry restrictions should be so modified that any concerns could be dispelled.

The skilled crafts sector has had to adapt to a new situation as a result of the integration processes within Europe and also increasing globalisation and this has presented trade legislation with challenges never before encountered. As part of this process, legislation needed to be realigned so that the adjustments required by the European Union could be executed. The principle of European law taking precedence has the effect of national law being subordinated to EU law. EU law and the associated jurisdiction define the conditions which national law must take into account to be in conformity with EU law. With the Trade and Crafts Code amendment of 2004 and, connected with this, the amendment to the EU/EEA Trade and Crafts Code, the legislators have carried out those adjustments that were postulated by EU law and the associated jurisdiction.

At this point, particular mention must be made of the freedom of establishment in Article 43 et seq. of the EC Treaty. The national regulations applied to EU foreigners discriminated against German craftsman. Without removing native discrimination, there was the latent danger that a German journeyman could invoke the principle of equality in Article 3 of the Constitution. It should be noted in this connection that both the introduction of the euro and the EU eastern expansion led to expectations of more intensive cross-border competition with the consequence that the problem of native discrimination would have worsened without the amendment.

In addition to this conflict between German and European law, there was an additional one from the freedom to provide services in Article 49 et seq. of the EU-treaty, in which distinctly lower hurdles for border-crossing activities were allowed. As compulsory membership and the payment of contributions would have been the consequence, the European Court of Justice prohibited in several judgements, the entry of EU foreigners carrying out border-crossing skilled crafts activities in the Register of Craftsmen. These judgements led directly to an obligation to adapt the Trade and Crafts Code. Thus, in order to carry out a border-crossing skilled crafts activity in Germany, the applicant merely required a certificate from the relevant local higher administration authority confirming that the applicant fulfilled the prescribed conditions to this effect in accordance with European law. The European allegiance to the German Trade and Crafts Code was therefore greatly called into question.

The comparison with regulations in other EU countries also shows the subordination of German 
law in this conflict. Only in a few countries, for example Great Britain, Poland or Ireland, are there entry restrictions in a few hazardous professions. A barrier comparable to the German regulation is only available in Luxembourg.

It was therefore logical that the Federal Republic of Germany's trade law would have to adapt completely to the less restrictive conditions of European law. Due to the fact that hardly any of the other European Union countries have trade legislation comparable to that of Germany and that they get by with considerably fewer regulations, it could not be expected, considering the deregulating measures in the EU, that German trade legislation would influence the EU trade legislation to its own advantage.

\section{Consequences of the Trade and Crafts Code amendment}

It was to be expected that more competitors would rush into the German market as a result of the easing of the Trade and Crafts Code regulations and the associated virtual abolition of the requirement for a Master's qualification. This increase in competition was not, however, to have been expected from the neighbouring European countries but mainly from within Germany. Market entry became possible for many craftsmen that were previously denied access due to the requirement for a Master's qualification. Although the demands for a relaxation of the Trade and Crafts Code and the abolition of the requirement to have a Master's qualification came from within Germany, European law was eventually the decisive factor in the legal situation which then emerged. It will be the established skilled crafts enterprises in particular that will find themselves exposed to tougher competition in the future those enterprises whose services are supplied by employed craftsmen and that also act as training establishments. Amongst the new competitors, there will mostly be smaller, often "one-man" businesses, that can offer their services at a more reasonable price thanks to a lower costs structure. Whether this will generate an advantage for the economy as a whole and society as a whole remains to be seen.

From a political point of view, many support the view that prosperity would rise with an increase in the number of self-employed. This connection cannot be established for certain. Precisely those EU countries with the highest rate of self-employed are typically the southern European countries where a negative correlation can be ascertained whereas the more prosperous northern European countries have a lower number of self-employed. The mere increase in self-employed does not automatically lead to an improvement in the quality of companies and consequently the prosperity of society as a whole. The call for an increase in the number of self-employed is therefore to be regarded critically. It is entirely conceivable that job creating growth - with a simultaneous decrease in the number of self-employed - could lead to greater social wealth. This assumption is strengthened by the fact that the start-up boom around 2004 was actually quantitatively supported by the smallest business units, mostly one-man enterprises that made no positive contribution to employment growth.

The question that remains to be considered is what were the consequences of the Trade and Crafts Code amendment for the national economy as a whole and, as a consequence, what conclusions can be drawn for the management of skilled crafts enterprises.

\section{The consequences of the Trade and Crafts Code amendment for the national economy}

The main reason for initiating the new version of the Trade and Crafts Code was that the number of enterprises in general and skilled crafts enterprises in particular in the Federal Republic of Germany had been decreasing for years and therefore also the number of employees in the skilled crafts sector. At the same time, numerous skilled crafts enterprises were not able to find a successor. It was therefore the declared aim of the amendment, in addition to the removal of native discrimination, to confront this structural crisis, to provide more employment especially through new company formations and takeovers of existing businesses.

Whilst it has been explained in detail that an arrangement complying with European law was found for the topic of native discrimination, the question remains as to whether the start-up and employment objectives have been achieved.

Initially on the basis of a clear increase in the number of enterprises, it would seem that the Trade and Crafts Code amendment definitely had an effect. This picture is shadowed, however, by the realization that there was a definite increase in the number of companies in all areas of industry and not just in the skilled crafts sector. Other possible reasons must therefore be considered. On the one hand, there are economic reasons. When the economy picks up, this is generally reflected in the number of new companies formed across all branches of industry. Furthermore, there was a definite effect from the change in subsidisation of self-employment out of unemployment. The changes made to start-up subsidisation have been considered a success. It can therefore be quite clearly stated that the number of enterprises quantitatively benefited from the change in subsidisation. That this also triggered a qualitatively acceptable development is to be seriously questioned at this point.

A further aspect relating to the skilled crafts sector is that numerous skilled crafts start-ups would not have been possible without the Trade and Crafts Code amendment, despite the change in start-up subsidisation. We can therefore conclude that the change in start-up subsidisation received a particular boost from the Trade and Crafts Code amendment as regards new company start-ups. 
The amendment boosted the success of start-up subsidisation and not the other way round.

The same can be said for new company formations resulting from EU eastern expansion. Numerous start-ups in the skilled crafts sector would not have been possible in this area without the easing of the Trade and Crafts Code regulations. The amendment therefore boosted start-ups by entrepreneurs from the newly acceded EU countries. The question still remains, however, as to whether the new start-ups - in particular from the area of the B2 skilled crafts - would have taken place anyway, though under another name.

Were these stimulating effects of clear benefit to the national economy as a whole? When we simply look at the development in the number of enterprises, we could answer this question in the affirmative but this would be more than a superficial assessment. For the new start-ups were generally very small concerns that could neither provide training nor any excessive value creation. Indeed, the opposite was the case. It can be assumed and this would provide material for a separate thesis - that the established enterprises lost their competitiveness and productivity due to partly ruinous competition. Now there may be something positive in this on first thoughts as especially lower prices for supposedly the same service could result in a higher volume of goods with the consequence of an increase in prosperity.

At the same time, however, established enterprises could restrict their investment activities and no longer carry out their important function of training young people in the profession and could therefore gradually go into decline. The question remains unanswered as to whether the new companies actually offer the same quality as had previously been offered. As has been clearly demonstrated, the training of human capital is no longer accorded the importance it used to have. It can therefore be seriously questioned whether the quality standard will be maintained in the long run.

If a decline in the quality standard does actually take place, the consequence will be that those companies who consistently invested in training, will be those that have the best chances of surviving in the future.

At the same time, a paradox becomes evident: in the analysis it was shown that the highest rate of growth in the number of enterprises was observable in those skilled crafts professions for which the company founders required a comparatively low level of knowledge and little start-up capital. But if the tendency to train dramatically declines in these professions, the consequence will be that there will be a lack of young trainees in relatively "simple" skilled crafts professions in the future. A consequence of this situation could be that there will be more "botchers" active on the market in the future and the customer will have to put up with lower quality for the lack of any better alternative. Alternatively, the fewer enterprises offering quality services would be able to force through inappropriately high prices. Both of these developments would be undesirable.

At the same time we must not forget that the topic of quality is particularly important in connection with liability for poor or deficient services. For precisely when a large proportion of skilled crafts work is provided by very small companies, the customer will quickly realize, that numerous suppliers can no longer be called on to comply with their guarantee obligations when required. For if a small company provides a poor standard of service, it has quite often disappeared from the market before having to comply with its guarantee obligations.

At the same time, it is important to note that no positive employment effects have resulted from the Trade and Crafts Code amendment. If at all, the numerous new start-ups in the area of small businesses - and especially in the Bl skilled crafts - compensated for job losses in the skilled crafts sector. New stimuli to drive employment growth which the amendment had hoped to encourage have not occurred.

All in all, we can ascertain that, superficially, company formations have been successful, many of which are definitely a result of the deregulation in admission requirements. However, the quality of these new company formations leads us to fear that the system of skilled crafts - established for centuries - is being damaged to such an extent that any positive effects are outweighed by much greater negative effects. In this connection, a reversal could be difficult against the background of European legal requirements.

We will just have to wait and see how far the market itself will manage to correct any undesirable developments. This could happen relatively quickly if, as a result of the less stable nature of new company formations, the skilled crafts enterprises with well trained and highly competent staff eventually win through despite their, to some extent, significantly higher prices. An indication to confirm this view could already be that there was a start-up boom in 2004 which has not recurred since. In this case it would be interesting to analyse how stable the numerous start-ups are and whether a cleansing of the market in the sense previously referred to has taken place.

As far as the national skilled crafts legislation is concerned, we can sum up that the wish for deregulation to release market potential is basically something to be welcomed and this is a truism. When implementing deregulation measures, attention should be paid to the fact that deregulation does not on balance produce economic losses which outweigh the benefits. Against the background of the historical development of Germany's skilled crafts and its resulting "separate approach" in Europe and in the world, the argument that "in other countries things are done differently and it still works alright" does not carry any weight. For 
skilled crafts legislation in Germany is more than "just" supplying the population with skilled crafts services. It is all about the quality of these services, also taking safety aspects into consideration and assuming responsibility for poor quality service. At the same time, the training benefits of the skilled crafts sector are of particular economic significance as the creation of human capital in this area does not only benefit the skilled crafts sector but the entire industrial economy. At the same time, we can conclude from the analysis that the employment effects hoped for as a result of deregulation have not occurred and that the Trade and Crafts Code amendment cannot be regarded as a success when measured against its postulated aims.

Economies in which the skilled crafts sector has developed differently, could argue about the sense of gradually raising the standards and therefore the level of regulations to an extent appropriate to the achievement of positive economic development, when the trend is towards a fundamentally lower level of regulation in the skilled crafts sector. This observation may not necessarily accord with the spirit of the time when we consider the EU's continuing trend towards deregulation. However, the aim of such regulation could be to raise the safety of hazardous professions, raise the quality of the work carried out - and so raise the wealth of the population and make it important for the skilled crafts to create human capital. The consequence would be the creation of larger skilled crafts enterprises instead of a vast number of small firms. This would result in permanent employment opportunities. Another benefit of more larger companies would be their tendency to make higher investments.

\section{SUMMARY}

The main objective is to evaluate, wether the objectives referring to the german craft code amendment in 2004 are achieved or not.

he results of this work can therefore be used at an international level for discussions on skilled crafts legislation outside Germany. As German skilled crafts legislation developed in a completely different manner from skilled crafts legislation in most other European countries, this aspect is particularly significant and it is conceivable that the results will be useful beyond the borders of the Federal Republic of Germany. The research findings will also be important in determining the limits of deregulation and when it can be considered counterproductive from an economic point of view. Moreover the results of the work should provide guidelines for the management of skilled crafts enterprises.

Initially on the basis of a clear increase in the number of enterprises, it would seem that the Trade and Crafts Code amendment definitely had an effect. This picture is shadowed, however, by the realization that there was a definite increase in the number of companies in all areas of industry and not just in the skilled crafts sector.

On the one hand, there are economic reasons. When the economy picks up, this is generally reflected in the number of new companies formed across all branches of industry.

Furthermore, there was a definite effect from the change in subsidisation of self-employment out of unemployment. We can therefore conclude that the change in start-up subsidisation received a particular boost from the Trade and Crafts Code amendment as regards new company start-ups. The amendment boosted the success of start-up subsidisation and not the other way round.

\section{REFERENCES}

ALBACH, H., 1992: Deregulierung des Handwerks, Wiesbaden, ISBN 3409131914.

ALBACH, H., 1989: Zur Wiederentdeckung des Unternehmens in der wirtschaftspolitischen Diskussion. Zeitschrift für die gesamte Staatswissenschaft, Heft 135, S. $535 \mathrm{ff}$.

BARNOWSKI-FECHT, S., 1998: Das Handwerk der Stadt Oldenburg zwischen Zunftbindung und Gewerbefreiheit (1731-1861), Oldenburg, ISBN 9783895987786.

BATTERMANN, D., 1997: Handwerker handeln im Markt: Grundlagen eines handwerksspezifischen Marketing. Europäische Hochschulschriften,
Reihe 5: Volks- und Betriebswirtschaft, Bd. 2181, Frankfurt/Main, ISBN 9783631324073.

BERSCHENS, R., 2000: „Prägnanter formulieren“, ZDH-Generalsekretär Schleyer zum Meisterzwang, in: Berliner Zeitung, Ausg. vom 16. 03. 2000, aus: www.berlinonline.de/wissen/ berliner-zeitung, Stand: 21. 02. 2003.

BERSCHENS, R., 2000: Union im Bundesrat kontra Trockenbauer, in: Berliner Zeitung, Ausg. vom 06.04.2000, aus: www.berlinonline.de/wissen/ berliner-zeitung, Stand: 13.02.2003.

Berufsverband unabhängiger Unternehmen e.V. (BUH), 1998: Stellungnahme des BUH zum XII. 
Hauptgutachten der Monopolkommission, Woltersdorf, 1998.

BLUM, U., 1998: Marktzugang und Exportfähigkeit deutscher Dienstleistungsunternehmen; Ausarbeitung zum Forum „Dienstleistungswirtschaft 2000 vom 06. Mai 1997“; Bundesministerium für Wirtschaft; Dokumentation Nr. 435, Brühl 1998, S. 131-151.

BRENKE, K., 2008: Reform der Handwerksordnung - Erfolgreich, aber viel zu halbherzig, in: DIW Berling (Hrsg.): Vierteljahreshefte zur Wirtschaftsforschung 77, Berlin, S. $51 \mathrm{ff}$.

BRORS, P., 2002: Handwerk hat doppelten Boden, in: Handelsblatt, Ausg. vom 07. 11. 2002, aus: www. handelsblatt.com, Stand: 28. 02. 2003.

Deregulierungskommission, 1998: Marktöffnung und Wettbewerb, Stuttgart 1991

Fredebeul-Krein, M. / Schürfeld, A.: Marktzutrittsregulierungen im Handwerk und bei technischen Dienstleistungen. Eine ökonomische Analyse, Köln, 1998.

FUCHS, B., DEMMER, W., 1998: W. Sitzung des Bund-Länder-Ausschusses „Gewerberecht", in: GewArch., S. 372 f.

GEHLEN, A., 1960: Die Seele im technischen Zeitalter, 3. Aufl., Hamburg.

GEISLER, B., 2003: Euro-Master statt Meister, in: Hamburger Abendblatt, Ausgabe vom 06. 01. 2003, aus: www.abendblatt.de, Stand: 21. 02. 2003.

GIERSCH, H., 1985: Eurosclerosis. Kieler Diskussionsbeiträge, 112, Kiel.

HAYEK, F. A., von, 1971: Die Verfassung der Freiheit, Tübingen.

HERZ, W., 2003: Wir sind gegen den Meisterzwang, in: Die Zeit, Ausgabe 04/2003, aus: www.zeus.zeit de/text/2003/04/Mittelstand-Interview, Stand: 31.01. 2003.

KAHLING, D., 2000: Wirtschaftsprüfung im Umbruch. Der Regierungsentwurf eines WPOÄnderungsgesetzes im Überblick. in: StuB, Ausg. 13/2000, S. $670 \mathrm{ff}$.

KfW: Das Handwerk im Wandel - Hat das Handwerk eine Zukunft?

KLEMMER, P., SCHRUMPF, H., 1999: Der Große Befähigungsnachweis im deutschen Handwerk, Relikt einer überkommenen Ständegesellschaft odermodernesInstrumentderWirtschaftspolitik?, Essen, RWI, ISBN 9783928739368.

KRUMBHOLZ, M., 1999: Entwurf des 7. Änderungsgesetzes zum StBerG und zur Änderung anderer Gesetze, in: StuB, 20/1999, S. $1096 \mathrm{ff}$.

KUCERA, G., STRATHENWERTH, W., 1989: Deregulierung des Handwerks, Gutachten erstellt im Auftrag der Deregulierungskommission beim Bundesminister für Wirtschaft, Göttingen, ISBN 9783509015560.

LEBMANN, Chr., 2005: Die Novelle der Handwerksordnung, Ich-Ags und die Folgen für das Bauhandwerk, in: ifo Institut (Hrsg.): ifo Dresden berichtet, Heft 6/2005, Dresden 2005, S. $28 \mathrm{ff}$.
MEYER, E., 1998: Berufsbild mit Schrammen, in: c`t 9/98.

Monopolkommission, 2002: Reform der Handwerksordnung, Sondergutachten der Monopolkommission gemäß § 44 Abs. 1 S. 4 GWB, BadenBaden 2002.

NEUBACHER, A., 2003: Kartell im Cyberspace, in: Der Spiegel, Ausgabe 10/2000 vom 04. 03. 2000, aus: www.spiegel.de, Stand: 04. 02. 2003.

Ohne Verfasser: Appell gegen „Meisterzwang in ITBetrieben, in: Computerwoche, Ausg. Nr. 48 vom 28. 11. 1997, S. 65.

Ohne Verfasser: Grüne wollen Reform, in. TAZ, Ausgabe Nr. 6940 vom 28. 12. 2002, S. 2.

Ohne Verfasser: Streit um den Meisterbrief, in: Rhein-Zeitung, Ausgabe vom 14.03.2003, S. 7.

PÚTZ, P., MEYERHÓFER, W., 1982: Hemmnisse und Hilfen für Unternehmensgründungen, Köln, ISBN 9783921471401.

RADEMAKER, B., 2003: Grüne wollen Handwerk reformieren, in: FTD, Ausgabe vom 27. 12. 2002, aus: www.ftd.de, Stand 28. 02. 2003.

Reformkommission Soziale Marktwirtschaft, 2003: Die Renaissance der Selbständigkeit, ohne Ort 1999, aus: www.buhev.de/2003/01/ reformkommission-smw.html, Stand: 31. 01.2003.

REICHLING, W., 1992: Wirtschaftliche Entwicklung und Perspektiven des Handwerks, in: Przybylski, Hartmut / Specht, Uwe (Hrsg.): Der Beitrag des Handwerks für eine menschlichere Gesellschaft, Bochumer Symposium Handwerk im Zeitalter der Automation, 25./26.10.199, Bochum 1992, S. 19 ff., ISBN 9783925895395.

SCHMIDT, M., 1992: Standesrecht und Standesmoral, Baden-Baden, ISBN 3789029149.

STOBBE, A., 1984: Volkswirtschaftslehre I, Volkswirtschaftliches Rechnungswesen, Berlin/Heidelberg/New York/Tokio, ISBN 9783540135753.

STOBER, R., 2001: Besonderes Wirtschaftsverwaltungsrecht, Gewerberecht und andere Wirtschaftszweige. Subventionsrecht, 12. Aufl., Stuttgart/Berlin/Köln, ISBN 3170178482.

STOBER, R., 1998: Gewerbeerlaubnisrecht, in: NWB Nr. 32 vom 03. 08. 1998, F. 30 S. 1159 ff.

STOBER, R., 1999: Gewerbeuntersagung, in: NWB Nr. 26 vom 28. 06. 1999, F. 30 S. 1235 ff.

STOBER, R., 1999: Wirtschafts- und Gewerbeüberwachung, in: NWB Nr. 5 vom 01. 02. 1999, F. 30 S. 1205 ff.

WACKER, H., 2003: Handwerksmeister, mehr als ein Titel, in: Hamburger Abendblatt, Ausg. vom 06. 01. 2003, aus: www.abendblatt.de, Stand: 21. 02. 2003.

WALLENBERG, G.V., 1995: Die Bedeutung des Meisterbriefs in Zeiten von Qualitätsmanagement und Europäischen Normen. Europäische Zeitschrift für Wirtschaftsrecht, Heft 6, München, S. $396 \mathrm{ff}$.

WESTERMANN, H.-P., 1974: Das Verhältnis von Standesregeln und guten Sitten im Wettbewerbsrecht, in: Fischer, Robert / Möhring, Philip / Westermann, Harry (Hrsg.): Festschrift für Carl Hans Barz, Berlin. 
Zentralverband des Deutschen Handwerks (ZDH), 1988: Stellungnahme zum Großen Befähigungsnachweis und zur Bedeutung der Handwerksordnung als Voraussetzung für den hohen Leistungsstand des deutschen Handwerks und die Sicherung hochwertiger Aus- und Weiterbildung im Interesse der Gesamtwirtschaft, Bonn.

Address

prof. PhDr. Wolfgang Benzel, MBA, Rothenbachstraße 4, D-55767 Oberbrombach, e-mail: wolfgang. benzel@datevnet.de 